International Journal of Instruction e-ISSN: 1308-1470 • www.e-iji.net

Article submission code: 20210115104322

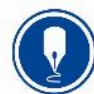

January $2022 \bullet$ Vol.15, No.1

p-ISSN: 1694-609X

pp. $821-836$

Received: 15/01/2021

Revision: 10/08/2021
Accepted: 05/09/2021

OnlineFirst: 28/11/2021

\title{
Social Responsibility as Curricular Content into Initial Teacher Training in time of Crisis
}

\section{$M^{a}$ del Carmen Pegalajar Palomino}

Corresponding author, Department of Pedagogy, Faculty Humanities and Education Sciences. University of Jaen, Spain, mcpegala@ujaen.es

\section{Estefanía Martínez Valdivia}

Department of Pedagogy, Faculty Humanities and Education Sciences. University of Jaen, Spain,evaldivi@ujaen.es

\section{Antonio Burgos García}

Department of Didactic and School Organization, Faculty of Education. University of Granada, Spain,aburgos@ugr.es

This research analyzes the level of social responsibility of undergraduate students in Early Childhood and Elementary Education from several Spanish universities $(\mathrm{n}=572)$. This analysis is considered a topic of interest for society which needs citizens who work ethically responsible and committed. Aspect that is especially relevant when it is talking about the teacher's professional work. The methodology used is quantitative, specifically, descriptive-correlational. In the collection of data, the research instrument is the 'Questionnaire of Social Responsibility of the University'. A descriptive analysis of data is performed; variables that predict the global evaluation of the student's level of social responsibility and a multiple linear regression are explored. Results show very positive values in all dimensions of the questionnaire (commitment to others and the environment, personal discovery of values, social responsibility training and approach to professional practice from social commitment). It is interesting to note that the level of global social responsibility of the student has been significantly associated with high levels of commitment to others and the environment, the personal discovery of values and the formation of social responsibility. Finally, social responsibility is necessary to legitimize the function of higher education and the knowledge it transmits to students.

Keywords: social responsibility, university training, professional ethics, initial teacher training, professional development 


\section{INTRODUCTION}

Currently, we are in an exceptional situation of health crisis at a global level produced by COVID-19. It has an important impact on the health, socio-economic, scientific, political and educational fields. The confinement and social isolation of the population, as a measure to prevent contagion, requires social responsibility and commitment to avoid the growth of the number of people infected by the virus and the collapse of health services. In the education sector, this health crisis has led to a suspension of education and the closure of schools. Teachers are obliged to promote teleworking by modifying their teaching-learning methods and to promote new techniques and tools for distance learning in order to continue the teaching process with their students. In this sense, it is also necessary to generate a teacher's social responsibility to advance in the teaching process with students, ensuring some basic methodological and organizational principles and establishing coordination relationships between the teachers involved. This situation allows the analysis of the social responsibility level of students in higher education, specifically in Education degree. This analysis is considered a topic of interest for society which needs citizens who work ethically responsible and committed.

Higher education has an important function; its growing trend towards internationalization and globalization has been included in the mission and vision of this institution (Suriansyah, Aslamiah, Noorhapizah, Winardi, \& Dalle, 2019). This function is related to offering an integral education to students. This aspect raises the interest in teaching values (personal-professional ethics and social responsibility). In this way, higher education trains people committed to the environment, a key aspect that influences their work as future teachers. This situation expresses the need to plan the curriculum and professional practices in a transversal way in different subjects (Lanzagorta, Rojas \& Sánchez, 2019).

Social responsibility has been a field of interest within the business world, although recently higher education institutions have incorporated this content into their policies and action plan. Currently, University Social Responsibility (USR) is of special interest when there are publications and different research that have been carried out in Latin American countries (Castillo, Mendoza, Plasencia \& Díaz, 2018; Gaete, 2016; Schwalb, Prialé \& Vallaeys, 2019; Vallaeys \& Álvarez; 2019). In our context (Spain) there are some studies on USR. These studies are not focused on the Social Responsibility of University Students (the subject of this article) because the literature is very limited. Some research works (García, De la Calle, Valbuena \& De Dios, 2016a, 2016b, 2016c) present key ideas and studies following the research`s line of Latin American context.

It is also a topic that currently takes on special interest, first of all, because it contributes to the comprehensive training that must be provided to students, acquiring, among other skills, being ethical professionals, with a high social commitment that allows them to acquire skills for the development of interpersonal relationships that leads him to create a coherent identity (Dayer, 2020). Aspect that conforms to the United Nations objectives set in the 2030 Agenda for Sustainable Development. Second, given the social and 
health situation that has been generated by the global pandemic, this training is necessary for students of education degrees in order to promote education for "prosociality". This term is understood as the voluntary action of one person to produce a benefit to another or to a group of people. It would be similar to the term "solidarity" (Morales, 2020). Such concepts are within the objective of university student social responsibility training that is so relevant today from an international perspective. Therefore, this research article aims to analyze ethics and personal values as an inherent part of social responsibility in the training of our future teachers.

\section{THEORETICAL FRAMEWORK}

Social Responsibility is a context of current analysis of globalization's phenomenon. This situation defines the establishment of relationships and the implementation of changes in institutions and organizations, in order to respond to the demands arising from society. Firstly, companies have different challenges related to new technologies, professional skills and producing-diffusing the knowledge generated with social responsibility (Niebles, Cabarcas \& Hernández, 2018). In this sense, Corporate Social Responsibility is defined as 'the voluntary integration by companies of social and environmental concerns into their business operations and relations with their stakeholders' (European Commission, 2019, 6).

This concept has been incorporated into the higher education context with nuances. University Social Responsibility aims to understand the social impact of higher education to contribute positively to the development of society (Gaete, 2016), from an organisational, social, cognitive, evaluate and educational perspective (Rodríguez, Cano \& Vélez, 2018; Andrades \& Larrán, 2015; Howells, Fitzallen \& Adams, 2016; Martínez, Gil-Salmon \& Macías, 2018; Martí, Calderón \& Fernández, 2019; Nagwa, 2019).

This research aims to determine the level of Social Responsibility of University Students in order to contribute to the educational impact of social responsibility (commitment) (García et al., 2016b). It is an 'added value' that integrates a tolerant attitude towards society. García et al. (2016b, 44), expresses the Social Responsibility of University Students as 'the ability and capacity to relate to others and non-fragmented knowledge of reality'. For this reason, the university student's training in social responsibility, ethics is important, as the 'personal value' of each one and the commitment to society.

Higher education must train future professionals in attitudes of responsibility towards society and ethical commitment. In this sense, it generates an educational function; Higher education must train people having as a reference a moral and ethical base, that leads them to develop a professional practice for the benefit of society (Vidal \& Oliver, 2017; Ismail, Muhammad, Kanesan \& Ali, 2019). In this way, higher education must connect the traditional functions, with innovations in undergraduate training:

- To promote student with values related to the moral, civic, affective and attitudinal dimensions;

- To encourage critical and reflective thinking and commitment to society and justice; 
- To educate active students with a global and integrated vision of society (respect and social justice);

- To promote solidarity in the knowledge society in diversity and personal development.

An interesting study developed in Spanish universities by Escámez, García-López \& Jover (2008) states that higher education institutions should train students in professional ethics, including among its aims, the training of competent citizens. In this sense, research by López \& Segarra (2011) states that ethics and social responsibility are more relevant in socio-economic Degrees (training of professional leaders). In this way, undergraduate students in Early Childhood and Elementary Education should receive training in social responsibility, because this student should work in the education of future citizens. Teachers must respond to the new demands and situations that define the educational system with responsibility and commitment. In this sense, in words of Howells, Fitzallen \& Adams (2016):

A greater awareness of the impact of their actions not only on their students but also on their emerging pedagogical practices, and the world at large, addresses the need within the profession to be graduating teachers who see teaching as a vocation that has positive influence (p. 64).

Ethics, applied in the field of teaching, is a substantial element in teacher training (Kafi, Motallebzadeh \& Ashraf, 2018). A 'good teacher' is a person who has acquired the professional competencies and acts in educational practice to contribute to social improvement (Tapia, 2019). These skills include competencies related to awareness (identification and recognition of emotions, self-efficacy), self-management (impulse control and stress management, help seeking), social awareness (empathy, respect for others), relationship management (communication, relationship building) and responsible decision making (problem solving, personal, social and ethical responsibility) (Ahmed, Hamzah \& Abdullah, 2020).

The values education of the undergraduate student is a priority issue for the higher education. This idea is expressed by the United Nations at the World Conference on Higher Education (2009). The main theme was social change, development and the lack of values in society. This situation is key to training in professional skills, specifically, in the ethics of citizenship, values such as commitment to peace, solidarity, defense of human rights and values related to democracy. In this sense, UNESCO (2016) proposes a Strategic Plan 2030. A key aspect is to achieve the objectives related to sustainable development and to guarantee quality education (UNESCO, 2016):

To ensure that students acquire the knowledge and skills to promote sustainable development, education and sustainable lifestyles, human rights, gender equality, the promotion of a peace and non-violence culture, global citizenship and the appreciation of cultural diversity and the contribution of culture to sustainable development' ( $p$. 48).

Ensuring quality education and commitment to sustainable development involves training university students in social responsibility. This allows the student to be a 
professional with ethical behavior in the exercise of their profession in the society and in its local community. According to Forster, Archer \& Tajin (2015), this aspect is considered as “(...) commonly used by universities as a measure of international success in various fields. It includes a criterion for Social Responsibility that indicates "engagement with local communities" (p. 171).

Higher education institutions included in this research have the educational part so relevant to today's society. These involved in the curricula of the Early Childhood and Elementary Education Degrees the presence of basic and general competences related to training in values and ethics as well as in social responsibility. Agbaria (2021) points out how the new educational reality requires the teacher to develop social and emotional skills.

In this sense, it can be seen in Table 1, there are different general competencies that higher education has adapted to the specific characteristics of the content taught for the Education Degree. All of them, in general terms, with the critical reflection of educational, ethical and personal practice and on actions related to social impact, promotion of collaborative work with colleagues and social entities, or need to acquire knowledge about the possibilities and limitations of education to face social responsibilities, which provide answers to the achievement of a sustainable and solidary future.

Table 1

General competencies in the education degree in Spain

\begin{tabular}{ll}
\hline Grade & General Competencies in Education Degree at Spain \\
\hline & C.F.B.14 - To promote actions of education in values oriented to the preparation of an active and \\
democratic citizenship. & C.F.B.22 - Relate education to the environment and cooperate with families and the community. \\
C.F.B.23 - Analyse and incorporate in a critical way the most relevant issues of today's society \\
that affect family and school education: social and educational impact of audiovisual languages \\
and screens; changes in gender and intergenerational relations; multiculturalism and \\
interculturality; discrimination and social inclusion and sustainable development. \\
C.P.7 - To know forms of collaboration with different sectors of the educational community and \\
the social environment \\
C.F.D.D.5 - Recognise the mutual influence between science, society and technological \\
development, as well as the relevant citizen behaviors, in order to ensure a sustainable future. \\
C.F.D.D.10 - To promote democratic education of citizenship and the practice of critical social \\
thinking.
\end{tabular}




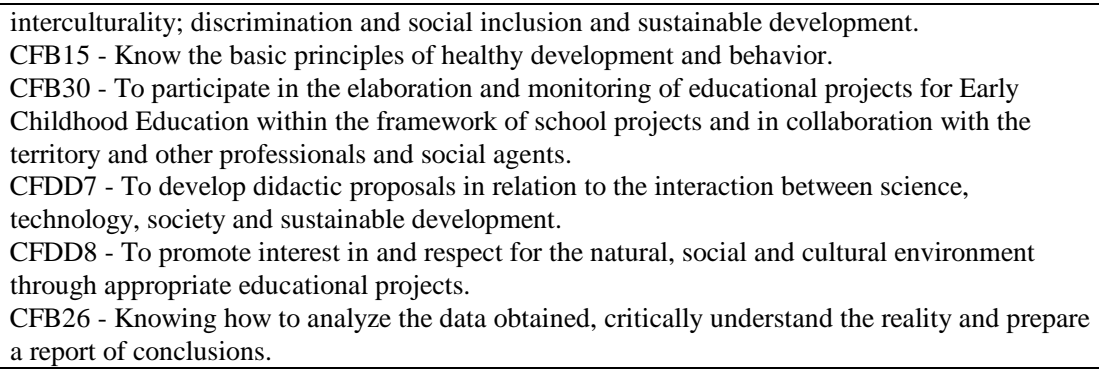

\section{METHOD}

The purpose of this research is to evaluate the level of social responsibility of undergraduate students in Early Childhood and Elementary Education. Specifically, this research responds to the following aims:

1. To evaluate student's capacity to commit to others, discovery personal values, training for social responsibility and the capacity of social commitment for a future professional practice;

2. To analyze relation between different variables, including the capacity for social responsibility in student;

3. To examine the predictive capacity of certain variables of the sample (gender, age and degree) on the level of social responsibility of the student.

This research has chosen a quantitative methodology, specifically, a descriptivecorrelational design, because it is a focus topic to the scientific community: university social responsibility and the professional ethical commitment of students involved in teacher training. This research analyzes a topic of interest to the scientific community (De la Calle \& Giménez, 2011).

\section{Participants}

Sample has aimed at undergraduate students assigned to an Education Degree (Early Childhood and Elementary Education), specifically, students from Spanish universities in Jaen and Granada. In this sense, according to data provided by the Academic Secretary of both higher education institutions, the total number of students enrolled in both Degrees for the 2019/20 academic year amounts to 1376 .

For the selection of the sample (incidental sampling), those students who have voluntarily answered the questionnaire $(n=572)$. The research team guarantees the representativeness of the sample, having used the formula for populations with less than 100,000 subjects with a $95 \%$ confidence level and a maximum estimation error of $4 \%$. The socio-demographic characteristics of the participating sample are presented below (table 2). 
Table 2

Socio-demographic data of the sample

\begin{tabular}{llll}
\hline Variable & Category & N & $\%$ \\
\hline \multirow{3}{*}{ Gender } & Man & 105 & 18.4 \\
\cline { 2 - 4 } & Woman & 467 & 81.6 \\
\hline \multirow{3}{*}{ Age } & Less than 20 years old & 261 & 45.6 \\
\cline { 2 - 4 } & Between 21-24 years old & 266 & 46.5 \\
\cline { 2 - 4 } & Between 25-29 years old & 25 & 4.4 \\
\cline { 2 - 4 } & More than 30 years & 20 & 3.5 \\
\hline \multirow{2}{*}{ Degree } & Early Childhood Education & 341 & 59.6 \\
\cline { 2 - 4 } & Elementary Education & 231 & 40.4 \\
\hline
\end{tabular}

\section{Instrument}

Data collection has been carried out through the research instrument 'Questionnaire of Social Responsibility of the University Student' (RSEU) in its original version designed by García et al. (2016b). It evaluates the level of commitment and social responsibility of undergraduate student. It included 21 items distributed according to four dimensions (Likert scale with 5 response options; 1=minimum agreement and 5=maximum agreement with the proposals on social responsibility). Each dimension refers to an aspect of the "student's social responsibility" construct:

- Items 1-5: Commitment to others and problems of the environment that demand urgent solutions;

- Item 6-10: Personal discovery of values (through the social responsibility, student requires values that lead to the recognition and respect of human dignity);

- Item 11-15: Social responsibility training (student is aware of the opportunity for learning and giving back to society the learn and contribution into social justice);

- Item 16-20: Approach to professional practice from a social commitment where social responsibility is learned and it offers student the opportunity to put that competence in practice;

- Item 21. The questionnaire includes an item-criteria, focused on the overall assessment of the level of social responsibility of the undergraduate student.

This instrument satisfies criteria of reliability and validity for the evaluation of the construct 'Social Responsibility of the University Student'. The validity of the content has been carried out by "expert judgment" (specialists in evaluation processes and in social responsibility) with extensive experience in the higher education context. The comments of these professionals have been positive, because they affirm changes in some items (writing). The analysis of the "criterion validity" confirms a high grade of reliability of the instrument (Cronbach's Alpha internal consistency index $=.923$ ). Furthermore, the work of García et al. (2016) expresses that this value is very satisfactory. It is confirmed by other statistical values, such as the Spearman-Brown coefficient (.856) and Guttman's "two halves test" (.852). The reliability analysis, according to dimensions, confirms Cronbach's Alpha value between .852 and .749. The Spearman-Brown coefficient for the reliability analysis for dimensions is between .858 
and .681, while the two-half Guttman coefficient is between .845 and .676 . The homogeneity indicators for all items are satisfactory (between 0.20 and 0.40 ). This situation explains that there are very significant correlations between dimensions demonstrated by the unidimensionality of the construct "Social Responsibility of the University Student". Finally, the "Exploratory Factor Analysis" analyses the construct validity of the instrument. It shows the existence of three significant factors that explain $56.45 \%$ of the variance. These factors are shown to be significantly correlated, which points to the unidimensionality of the construct "Social Responsibility of the University Student" on a three-dimensional basis.

\section{Data collection}

The questionnaire has been administered through the survey's application 'Google Forms' (Figure 1). The research team had access to the sample in class time to ensure the validity of the procedure in the data collection. Previously, students have been informed about the aim of the research, the content of the survey, as well as those other issues considered of interest by the research team. At the same time, students have been informed of the confidentiality and protection of the data collect.

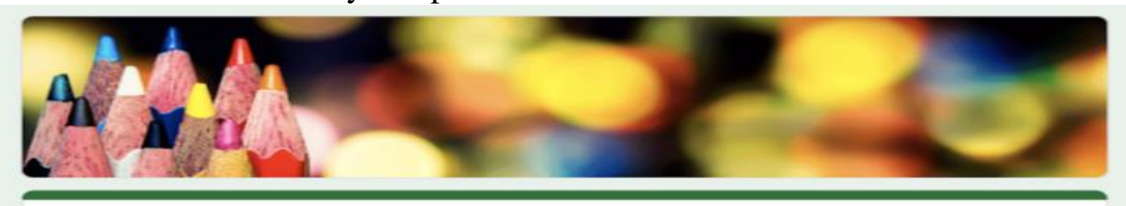

\section{University Social Responsibility Questionnaire}

The following questionnaire aims to research your level of training on Social Responsibility. In this regard, we ask you to answer the following questions honestly. This questionnaire is anonymous and guarantees the confidentiality
of the data collected.

Thank you for your cooperation

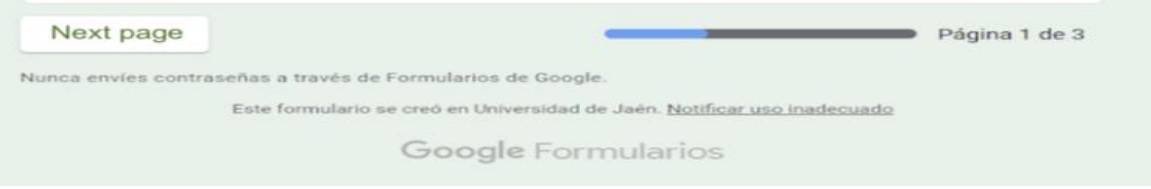

Figure 1

Questionnaire in the survey's application 'Google Forms' (https://forms.gle/7rWDYyy4h2oTxBB18)

\section{Data analysis}

Statistical analysis of the data has been done with the SPSS software (version 25 for Windows). In this way, a descriptive analysis of data is performed, taking as a reference, the value obtained in each of the scores, standard deviations and the level of internal consistency of the scale, as well as the level of relationship between its dimensions (Cronbach's alpha). Finally, this research explores the variables that predict the student's global assessment of social responsibility and a multiple linear regression analysis. 


\section{FINDINGS}

Aim 1 "To evaluate a student's capacity to commit to others, discover personal values, training for social responsibility and the capacity of social commitment for a future professional practice" has been carried out a descriptive analysis with average scores (Standard Deviations).

Results show high values for all dimensions (obtaining greater scores in 4 cases). Furthermore, taking as a reference the criterion variable (groups the overall assessment level student's social responsibility) $(\mathrm{M}=4.1 ; \mathrm{SD}=0.75)$, results show very favourable estimates (table 3).

Table 3

Means (Standard Deviations), reliability and correlations between dimensions

\begin{tabular}{|c|c|c|c|c|c|c|c|}
\hline & Means (SD) & Alpha & Criterion & D1 & D2 & D3 & D4 \\
\hline Criterion item & $4.1(0.75)$ & & 1 & & & & \\
\hline $\begin{array}{l}\text { D1. Commitment to others } \\
\text { and environment }\end{array}$ & $4.21(0.55)$ & 0.751 & $0.514^{*}$ & 1 & & & \\
\hline $\begin{array}{l}\text { D2. Personal discovery of } \\
\text { values }\end{array}$ & $4.43(0.49)$ & 0.714 & $0.444 *$ & $0.565^{*}$ & 1 & & \\
\hline $\begin{array}{l}\text { D3. Social responsibility } \\
\text { training }\end{array}$ & $4.06(0.64)$ & 0.727 & $0.383^{*}$ & $0.432 *$ & $0.425^{*}$ & 1 & \\
\hline $\begin{array}{l}\text { D4. Approach to } \\
\text { professional practice based } \\
\text { on social commitment }\end{array}$ & $4.52(0.47)$ & 0.767 & $0.378^{*}$ & $0.497 *$ & $0.599 *$ & $0.521 *$ & 1 \\
\hline
\end{tabular}

$* \mathrm{p}<.001$.

The aspects related to social responsibility that obtained the highest scores, are dimension 4 focused on 'Approach to professional practice based on social commitment' $(\mathrm{M}=4.52 ; \mathrm{SD}=0.47)$ and dimension 2 associated with 'Personal discovery of values' $(\mathrm{M}=4.43 ; \mathrm{SD}=0.49)$. Thus, the importance that student's attributes to the personal values learned in higher education in order to act as a socially responsible expert in the future professional activity is emphasized.

The high score obtained in the indicator of dimension 1 is 'Commitment to others and environment' $(\mathrm{M}=4.21 ; \mathrm{SD}=0.55)$. In this way, undergraduate students are preparated to lead social changes, based on the analysis and their involvement with the global problems of society and in the exercise of their professional capacity.

Dimension 3 associated with 'Social responsibility training' $(\mathrm{M}=4.06$; $\mathrm{SD}=0.64)$ has obtained the lowest score. Nevertheless, there is agreement among university students in valuing the privilege and commitment that access to higher education implies for the development of competence related to social responsibility.

Aim 2 "To analyze relations between different variables, including the capacity for social responsibility in students" has carried out a correlation analysis using Pearson's $r$ index. 
Results show that there is a correspondence between all dimensions of the questionnaire, having obtained a greater level of relationship between the student's assessment of the professional practice from the point of view of social commitment and personal discovery of values $(r=.599)$, and between the latter and the commitment to others and environment $(\mathrm{r}=.565)$. The dimension linked to the approach to professional practice has also obtained a high correlation with the valuation of students towards social responsibility training $(\mathrm{r}=.521)$, as well as obtaining a high level of correlation between the global valuation of students and the commitment to others and environment $(r=.514)$.

Finally, aim 3 "To examine the predictive capacity of certain variables of the sample (gender, age and degree) on the level of social responsibility of the student" has carried out a multiple linear regression analysis (step by step) (table 4).

Table 4

Influence of demographic variables and dimensions on total social responsibility

\begin{tabular}{|c|c|c|c|c|c|c|}
\hline \multirow[b]{2}{*}{ Variables } & \multicolumn{3}{|l|}{ Step 1} & \multicolumn{3}{|l|}{ Step 2} \\
\hline & $\mathrm{B}(\mathrm{ET})$ & $\mathrm{t}$ & r partial & $\mathrm{B}(\mathrm{ET})$ & $\mathrm{t}$ & r partial \\
\hline \multicolumn{7}{|l|}{ Socio-demographic } \\
\hline Gender (Male/Female) & $\begin{array}{l}0.04 \\
(0.09) \\
\end{array}$ & 0.44 & 0.019 & $\begin{array}{l}0.21 \\
(0.08)\end{array}$ & $2.76^{* *}$ & 0.118 \\
\hline Age & $\begin{array}{l}0.01 \\
(0.01) \\
\end{array}$ & 1.15 & 0.049 & $\begin{array}{l}0.00 \\
(0.01)\end{array}$ & 0.13 & 0.006 \\
\hline $\begin{array}{l}\text { Grade of Education (Early } \\
\text { Childhood/Elementary Education) }\end{array}$ & $\begin{array}{l}-0.12 \\
(0.07) \\
\end{array}$ & -1.72 & -0.074 & $\begin{array}{l}-0.06 \\
(0.06) \\
\end{array}$ & -1.01 & -0.044 \\
\hline \multicolumn{7}{|l|}{ Dimensions } \\
\hline $\begin{array}{l}\text { 1. D1. Commitment to others and } \\
\text { environment }\end{array}$ & & & & $\begin{array}{l}0.47 \\
(0.06) \\
\end{array}$ & $7.52 * * *$ & 0.309 \\
\hline D2. Personal discovery of values & & & & $\begin{array}{l}0.28 \\
(0.07) \\
\end{array}$ & $3.76 * * *$ & 0.161 \\
\hline $\begin{array}{l}\text {. D3. Social responsibility } \\
\text { training }\end{array}$ & & & & $\begin{array}{l}0.17 \\
(0.05) \\
\end{array}$ & $3.23 * *$ & 0.139 \\
\hline $\begin{array}{l}\text { 4. D4. Approach to professional } \\
\text { practice based on social commitment }\end{array}$ & & & & $\begin{array}{l}0,06 \\
(0,08) \\
\end{array}$ & 0.83 & 0.036 \\
\hline $\mathrm{R} 2(\%)$ & 0.4 & & & 31.8 & & \\
\hline$\Delta \mathrm{R}^{2}(\%)$ & & & & 31.4 & & \\
\hline Model & $\mathrm{F}(3,534)$ & 1.65 & & $\mathrm{~F}(7,534)$ & $6.98 * * *$ & \\
\hline
\end{tabular}

Demographic variables (step 1) and scale dimensions (step 2), both of them, have been included as predictors to determine the effect of these variables on the student's overall assessment of social responsibility.

In step 1, the contribution of demographic variables has been verified, showing that none of them contributes significantly to the overall assessment of social responsibility in students. However, the addition of the dimensions of the scale on social responsibility in the model (step 2) has shown a significant increase in the percentage of variability explained, reaching $31.8 \%$ in this step. 
Socio-demographic variables, it is demonstrated that the gender of students has a statistically significant effect on the overall assessment, in terms of social responsibility. More specifically, men claim to have a better level of social responsibility than women (B $=0.89, \mathrm{p}=.006)$.

For the different dimensions of the scale, the student's level of global social responsibility has been significantly associated with high levels of commitment to others and environment $(\mathrm{B}=0.47, \mathrm{p}<.001)$, personal discovery of values $(\mathrm{B}=0.28, \mathrm{p}<.001)$ and training of social responsibility $(\mathrm{B}=0.17, \mathrm{p}=.001)$. Respecting the predictive of the significant variables ( $\mathrm{r}$ partial in absolute value), the commitment to others and environment has turned out to be the best predictor of social responsibility, followed by the personal discovery of values, social responsibility training and student's gender.

Finally, we have obtained an analysis of the residual, predictives values and verification of the suitability assumptions of the complete regression model (step 2). Results show compliance with the assumption of normality, independence and homoscedasticity. Thus, the test of normality, (Kolmogorov-Smirnov test $-\mathrm{p}=.153-$ ) allows the acceptance of the null hypothesis, which confirms the normal distribution of errors. Also, the independence of the errors obtained by means of the Durbin-Whatson test ( $D W=2.013$ ) allows assumed independence among the wastes because their value is between 1.5 and 2.5 (Durbin \& Whatson, 1971). The assumption of homocedasticity has been evaluated by means of the Levene test $(\mathrm{p}=.321)$, and it has been verified that the variance of the wastes is constant.

\section{DISCUSSION}

This research has made it possible to analyse the current state of the level of social responsibility of undergraduate students in Early Childhood and Primary Education at several Spanish universities, taking as a reference, the curricular content of their initial training and the health crisis situation caused by COVID-19.

In times of crisis, training is not always enough. Sometimes, it is necessary to use tools, methodologies and education and didactics strategies, so that society can understand this exceptional crisis situation caused by the coronavirus. Teachers have an essential role to stop this pandemic. If we put our educational knowledge at the service of society, we can help a lot.

In this sense, teacher training is the key to generate the capacity for commitment to others, through the exercise of critical thinking in this pandemic situation. This statement coincides with Bustamante \& Navarro (2007) because university students must acquire socially responsible behaviour towards shared spaces in times of economic, social-health crisis and social coexistence.

In any case, 'crisis situations' are not desirable, but these 'situations' can help us to learn things that will be useful throughout our lives and that will help us to face other crises with a well-prepared "toolbox"' (UNICEF, 2020, 2). This study is a practical evidence and a real example of the discourse expressed by the United Nations (2009) and 
UNICEF (2020); it expresses the need and prioritisation of values training for university students, due to social change, loss of values and social-health crisis.

This research shows that this discourse should be introduced in initial teacher training, because students attribute to their university studies the ability to modify their own values. For example, this study expresses a high capacity for professional/personal exercise and social commitment on students. A second interesting aspect of initial teacher education is personal values. The importance of these values should be directed towards a commitment to behaviours and attitudes linked to close experiences that have the socio-professional context of university students as a reference (Navarro et al., 2012).

Also, it is important to find out that kind of training should be key to making social responsibility and commitment an essential part of professional teaching practice. This idea implies knowing the meaning that students give to training in relation to social responsibility in higher education. Training for social responsibility is not well valued in general, although there is a consensus among students when the acquisition of a higher level of competence and social responsibility is determined, on the one hand, by access to a higher education degree, and on the other hand, in the words of Castillo et al. (2018, 11), '(...) training must adopt a cooperative learning methodology and be carried out from a collaborative perspective'.

Another key aspect of this study is the "power" of social responsibility in teaching. In this sense, this survey confirms the research of Forster et al. (2015) and Arango et al. (2014) when our study states that the "power" is in the commitment and respect for others with reference to social change and global problems of our society. This type of commitment is defined as "contextual" and "community". Forster et al. (2015) and Arango et al. (2014) express that when establishing a direct relationship between academic training, empathy and participation in non-governmental organisations produce professional practices with a socially responsible value and behaviour.

Likewise, Oseda et al. (2019) expresses a similar methodological and formative position. There is a direct and highly significant correlation between environmental education and social responsibility in the training of university students. Furthermore, Arango et al. (2014) add specific aspects and important details such as behaviours linked to self-care, ecology/environment and respect for shared spaces.

Finally, another key aspect of this research is the predictive capacity of certain variables in the sample (gender, age and degree). These variables are related to social responsibility level in the teacher training. This predictive ability is demonstrated when the student's 'gender' variable has a statistically significant effect on the overall assessment of the concept of "social responsibility" of students. Specifically, our study affirms that male students have a higher degree of social responsibility than female students. This statement partially confirms the study developed by Castillo et al. (2018); they identify a higher level of social responsibility among university students and that they have a higher academic performance. 


\section{CONCLUSIONS}

University social responsibility is necessary to legitimise higher education as an "institution" and the knowledge that is transmitted to university students. In this sense, the commitment to others must be the "central axis" of social responsibility. This aspect is very important. "Social responsibility" concept allows teachers to have the possibility of being able to make a solid "curricular adaptation" for a current socio-health crisis situation.

Anyway, in crisis situations, higher education must legitimise this concept, because it is necessary to train teachers, to produce investigations, etc. This guarantees a reliability and validity 'not accommodated' to the desires and geopolitical interests of different countries (Vallaeys \& Alvarez, 2019). Therefore, it is essential that students are key to know how to train and include social responsibility in the curricula because, as Howells et al. (2016) express, teaching students about social responsibility gives a new role to teachers as "agents of change". Also, "school" is a space for equality, cooperation and social justice where "(...) children are treated equally, far from the personal situation that each one has at home. At school they see another way of thinking, acting and walking (...)". This situation shows the learning of the concept of social responsibility" (2016, 55). Higher education institutions should be places of social responsibility training to students, because these institutions provide valid knowledge and experiences that will be extrapolated to the workplace from a "rational", "scientific" and socially committed perspective.

Finally, it is important that this research can be a basis for future investigations. In this sense, one limitation was to analyse the curricular training together with the perception, needs and beliefs of "university professors" (key agents in the training of future experts, technicians and professionals who will work in some productive area of society). It also highlights the role that public and private institutions should play and, whether, they provide spaces and resources to successfully extend the social responsibility concept to all areas and productive sectors of society.

\section{REFERENCES}

Agbaria, Q. (2021). Classroom management skills among kindergarten teachers as related to emotional intelligence and self-efficacy. International Journal of Instruction, 14(1), 1019-1034. https://doi.org/10.29333/iji.2021.14160a

Ahmed, I., Hamzah, A.B., \& Abdullah, M. (2020). Effect of social and emotional learning approach on students' social-emotional competence. International Journal of Instruction, 13(4), 663-676. https://doi.org/10.29333/iji.2020.13441a

Andrades, F.J. \& Larrán, M. (2015). Analysis of university social responsibility from different theoretical approaches. Revista Iberoamericana de Educación Superior, 6(15), 3-20. http://dx.doi.org/10.2220120072872e.2015.15.144 
Arango, O., Clavijo, S., Puerta, I. \& Sanchez, J. (2014). Academic training, values, empathy and socially responsible behaviour in university students. Revista de la Educación Superior, 43(169), 89-105. http://dx.doi.org/10.1016/j.res.2015.01.003

Bustamante, M.J. \& Navarro, G. (2007). Self-attribution of socially responsible behaviors of social science career students. Perspectives Magazine, 18, 45-63. https://.doi.org/10.14198/OBETS

Castillo, Y., Mendoza, B., Plasencia, E. \& Díaz, C. (2018). Degree of social responsibility in students of a public university. Revista Cubana de Educación Médica Superior, 32(2), 1-13. Retrieved from: https://www.medigraphic.com/cgi$\mathrm{bin} /$ new/resumenI.cgi?IDARTICULO $=85808$

Dayer, M.C. (2020). The relevance of social commitment from lexperiential learning", thought in the context of the 2020 pandemic. Nuevas Propuestas, 55, 80-89.

De la Calle, C. \& Giménez, P. (2011). Approach to the concept of Social Responsibility of the University. Journal Communication and Man, 7, 236-247. https://doi.org/10.13042/Bordon.2016.68303

Durbin, J. \& Watson, G.S. (1971). Testing for serial correlation in least squares regression III. Biometrika, 58, 1-19. https://doi.org/10.2307/2334313

Escámez, J., García-López R. \& Jover, G. (2008). Restructuring university degree programmes: a new opportunity for ethics education? Journal of Moral Education, 37(1), 41-53. https://doi.org/10.1080/03057240701803676

European Commission (2019). Commission staff working document. corporate social responsibility, responsible business conduct, and business \& human rights: Overview of progress. Brussels: European Commission.

Forster, D.J., Archer, J., \& Tajin, R.T. (2015). Volunteering within initial teacher education: factors that boost and block participation. Australian Journal of Teacher Education, 40(11), 169-184. http://dx.doi.org/10.14221/ajte.2015v40n11.10

Gaete, R. (2016). University student leaders' perception of university social responsibility. OBETS. Revista de Ciencias Sociales, 11(2), 461-485. http://dx.doi.org/10.14198/OBETS2016.11.2.04.

García, J.M., De la Calle, C., Valbuena, M.C. \& De Dios, T. (2016a). Training in social responsibility and its impact on various university careers. Revista de Investigación Educativa, 34(2), 435-451. http://dx.doi.org/10.6018/rie.34.2.244271.

García, J.M., De la Calle, C., Valbuena, M.C. \& De Dios, T. (2016b). Towards the validation of the 'Social Responsibility of University Students' (SRS) construct. Bordón, 6(3), 41-48. 
García, J.M., De la Calle, C., Valbuena, M.C. \& De Dios, T. (2016c). Social responsibility: an element of training for university students. Revista Latinoamericana de Estudios Educativos, 14(1), 1-12. http://dx.doi.org/10.17151/rlee.2018.14.1.6

Howells, K., Fitzallen, N., \& Adams, C. (2016). Using assessment to develop social responsibility as a graduate attribute in teacher education. Australian Journal of Teacher Education, 41(6), 52-67. http://dx.doi.org/10.14221/ajte.2016v41n6.4

Ismail, S. N., Muhammad, S., Kanesan, A. G., \& Ali, R. M. (2019). The Influence of Teachers' Perception and Readiness towards the Implementation of Critical Thinking Skills (CTS) Practice in Mathematics. International Journal of Instruction, 12(2), 337352. https://doi.org/10.29333/iji.2019.12222a

Kafi, Z., Motallebzadeh, K., \& Ashraf, H. (2018). University Instructors' Teaching Experience and Their Perception of Professional Ethics: Postulating a Model. International Journal of Instruction, 11(4), 257-270. https://doi.org/10.12973/iji.2018.11417a

Lanzagorta, M.C, Rojas, G.J. \& Sánchez, D.E. (2019). Perception of the relationship between integral formation and social responsibility from students. International $\begin{array}{llll}\text { Journal of advanced } & \text { 68search, } & \text { 7(11), }\end{array}$ http://dx.doi.org/10.21474/IJAR01/10058.

López, M.A. \& Segarra, M. (2011). Attitudes of business administration students towards corporate social responsibility and business ethics. Revista Complutense de Educación, 22(2), 235-248. http://dx.doi.org/10.5209/rev_RCED.2011.v22.n2.38491.

Martínez, M.J., Gil-Salom, D. \& Macías, D. (2018). Systematic review of university social responsibility and service learning: Analysis for its institutionalisation. Revista Mexicana de Investigación Educativa, 24(80), 149-172. Retrieved from: https://cutt.ly/fbMxgTL

Martí, J.J., Calderón, A.I. \& Fernández, A. (2019). University social responsibility in Latin America: analysis of the legislation of Brazil, Spain and Peru. Revista Iberoamericana de Educación Superior, 9(24), 107-124. https://doi.org/10.22201/iisue.20072872e.2018.24.264

Morales, F, M. (2020). Estrategias de afrontamiento, empatía y tendencia prosocial en universitarios. European Journal of Education and Psychology, 13(2), 187-200. https://doi.org/10.30552/ejep.v13i2.360

Nagwa, A.Y. (2019). Ajman University students' perspectives on university social responsibility: A field study. Opción, 35, 11-32. Retrieved from: https://produccioncientificaluz.org/index.php/opcion/article/view/24403

Navarro, G., Boero, P., Jiménez, G., Tapia, L., Hollander, R., Escolar, A., Baeza, M. \& Espina, A. (2012). Socially responsible values and attitudes in Chilean university 
students. Quality in education, 36, 123-147. http://dx.doi.org/10.4067/S071845652012000100004

Niebles, W., Cabarcas M. \& Hernández, H. (2018). Social responsibility: an element of formation in university students. Revista Latinoamericana de Estudios Educativos, 14(1), 95-108. http://dx.doi.org/10.17151/rlee.2018.14.1.6.

Oseda, D., Sangama J.L., \& Añaños, M.A. (2019). Environmental education and social responsibility in university students in the Ucayali region, Peru. Option, 35(89), 347365.

Rodríguez, G., Cano, E. \& Vélez, X. (2018). Social university responsibility: an approach to the public university's relationship with the student. Revista ECA Sinergia, 9(1), 24-36. Retrieved from: https://revistas.utm.edu.ec/index.php/ECASinergia/article/view/962/1224

Schwalb, M. M., Prialé, M.A. \& Vallaeys, F. (2019). Guide to university social responsibility. Peru: Universidad del Pacífico.

Suriansyah, A., Aslamiah, A., Noorhapizah, N., Winardi, I., \& Dalle, J. (2019). The relationship between university autonomy, lecturer empowerment, and organizational citizenship behavior in indonesian universities. Journal of Social Studies Education Research, 10(4), 127-152. Retrieved from: https://www.learntechlib.org/p/216543/.

Tapia, G.A. (2019). Concepts and criteria of evaluation of university teaching staff belonging to the humanities on the relationship between ethics and teaching excellence. Sociological Praxis, 24, 201-216.

UNESCO (2009). World Conference on Higher Education, 2009: The new dynamics of higher education and research for societal change and development. Communiqué. Retrieved from: http://-bit.ly/1on8wrg

UNESCO (2016). Education 2030. Incheon Declaration and framework for action for the implementation of sustainable development goal 4. Retrieved from: http://www.unesco.org/new/es/santiago/education2030/

UNICEF (2020). \#educaCOVID19: Why is it important to educate about the new coronavirus?. Retrieved from:

https://www.unicef.es/educa/blog/covid19-por-que-es-importante-educar-sobre-elnuevo-coronavirus

Vallaeys, F. \& Alvarez, J. (2019). Towards a Latin American definition of university social responsibility. An approach to the conceptual preferences of university students. Education XX1, 22(1), 93-116. http://dx.doi.org/10.5944/educXX1.19442.

Vidal, P. \& Oliver, E. (2017.) Education quality and teaching ethics from the perspective of teachers in training. Edetania, 52, 243-268. Retrieved from: http://revistas.ucv.es $>$ download $>$ edetania-52-pdf-es 